\title{
Learning habits of civil engineering students at the University of Sucre during COVID-19
}

\author{
Fernando Jove Wilches*1, Jhon Jairo Feria Díaz ${ }^{1}$ and Rodrigo Hernández Avila ${ }^{1}$ \\ ${ }^{1}$ Department of Civil Engineering, Universidad de Sucre, Sincelejo, Sucre, Colombia.
}

\begin{abstract}
ORCIDs: 0000-0002-2080-4036 (Fernando), 0000-0003-1397-1546 (Jhon), 0000-0003-3178-8075 (Rodrigo)
\end{abstract}
\begin{abstract}
The pandemic generated by the presence of the new coronavirus COVID-19, has undoubtedly been one of the events that has caused the greatest impact on society worldwide in recent times, taking the world by surprise and generating a great impact at the level global, because society in general and the political and socio-economic systems of the different countries were not prepared to face the challenge generated by the long quarantine periods decreed by the different governments. One of the fields that has been hit the hardest worldwide, and especially in developing countries like Colombia, has been education. This has been seriously affected by the drastic change in the way of carrying out the teachinglearning process, as the educational system had to adapt, unexpectedly, from face-to-face to virtual, without it being prepared for such end. Hence the importance of being able to have first-hand information, which allows to know the degree of affectation generated by the change of methodology in education. This document presents the socioeconomic information and aspects related to the use of online tools and their potential impact on the educational process, based on a survey carried out among 4 and 5 year old Civil Engineering students from the University of Sucre, which is of public, located in the city of Sincelejo, North of Colombia. In response to the recent crisis of the COVID-19 pandemic, the University of Sucre was forced to change the traditional classroom teaching model, for an virtual system, in which students and teachers attend synchronous sessions in virtual media and asynchronous for the development of academic activities. The authors designed a questionnaire to characterize the socioeconomic conditions of the students and evaluate the impact generated by the use of digital learning tools. The applied questionnaire consists of two main sections: the first, which seeks to know the sociodemographic situation of the students, with questions such as sex, age, institutions, income, among others. The second part of the interview is aimed at understanding the use of digital tools by students and their impact on the development of their academic performance, for which questions are asked in which conditions are evaluated before COVID-19 and during COVID-19.
\end{abstract}

Keywords: Education management, Student satisfaction, Learning habits, Distance learning, video conferencing tools, COVID-19.

\section{INTRODUCTION}

Education is a fundamental aspect when seeking the development of society and personal growth in the individuals of a territory. From this, the social and economic conditions to which the population of a certain territory is linked can be changed and it directly influences the quality of life of these people. This is more visible in third world countries like Colombia, in which poverty is linked to educational level. Hence, education is perhaps one of the most effective tools to reduce inequality and achieve equal conditions for income generation. Through an equitable, quality and relevant education, the population can more easily access formal employment or undertake a business initiative with greater chances of success, in addition to being able to allow the growth and personal development of individuals [1].

Education should be sought for its quality and not for its quantity, which is comprehensive and is accompanied by the ethical development of the personality and the constant desire to improve, without forgetting the environment and social responsibility [2]. To achieve this, the tools and processes to impart education must be guaranteed, with institutions, teachers, programs and materials according to the competencies sought. If all these requirements are met, the education provided is more likely to be of quality.

At present, the recent and unexpected situation that surprised the world with the Covid-19 pandemic, has brought new challenges in all aspects of daily life, among them, in the educational field, directly affecting students, teachers, centers educational, managers and the families of those involved. The health emergency has led to the massive closure of face-to-face activities of educational institutions in more than 190 countries, in order to prevent the spread of the virus and mitigate its impact [3]. This closure of educational institutions has millions of Latin American students without attending their learning processes in person.

The prolonged closure of educational centers will have negative repercussions on the learning achieved, schooling on time, dropouts and promotion. This situation may be further aggravated in educational systems that do not have effective distance education mechanisms according to the characteristics of the homes, which can further widen the gaps that exist between students with more or less access to them [4]. 
In the case of Colombia, according to the Laboratory of Economics of Education (LEE) of the Javeriana University, great deficiencies are noted to face the pandemic, among the most common, there is a lack of technological equipment such as computers or coverage non-existent or deficient internet in many populations of the country [5]. In addition to this, it must be clear about how these new forms of teaching affect the student, in this way it is possible to try to administer more suitable alternatives that achieve a more enjoyable and effective education.

The objective of this document is focused on characterizing the sociodemographic conditions of a sample of students from the University of Sucre, located in the department of Sucre, north of Colombia. It seeks to make a contrast of the conditions and habits of students in their educational process, in the months before the Covid-19 pandemic and during the pandemic, to look at study habits and the changes generated, as a result of changing from a face-to-face education to one from virtuality. Additionally, it inquiries about the tools, equipment and connectivity available to carry out the learning process and what is the impact and changes that this pandemic has brought in the daily lives of students.

\section{EXPERIMENTAL DESIGN, MATERIALS AND METHODS}

Data collection was carried out between August 3 and 14, 2020, through an online survey conducted with a representative number of undergraduate students from the civil engineering program of the University of Sucre. The ages of the participating students ranged from 20 to 32 years. The survey took an average of 5-10 minutes to fully answer. The main objective of the questionnaire was to collect representative sociodemographic data, the conditions of virtual education and the impact and perception of said learning methodology in university students. Online sources such as WhatsApp and email were used to share the questionnaire with the students. A questionnaire that was designed in Google Forms, provided by the google company as part of its service package, was used to develop and distribute the survey.

The main objective of the data collection was to obtain information about the perception of undergraduate students in their learning process, comparing the habits and activities they carried out during the first two months of classes (before COVID-19 was declared a pandemic in Colombia) and the last two months of the academic semester (where classes were taught virtually, due to government restrictions to curb the outbreak of the pandemic). As is known, the pandemic has had an impact on university students in countries of the world where it has presented a notable development [6], [7], [8]. In countries like Colombia, traditionally it has worked with a faceto-face model for the development of the educational process, and it can be noted, as in other countries, that the satisfaction of students within the teaching-learning process is closely linked to the presence of the teacher in the classroom [9]. Therefore, it is extremely important to know the degree of impact that non-face-to-face education [10] can generate on students' academic performance. As a result of the quarantines implemented to face the pandemic, students have had to change their learning habits almost obligatorily [11]. In the case of the
University of Sucre, its students had to adopt a completely new learning methodology for them, taking into account that by regulation, the modality established for the development of the classes is in person. This work seeks to record the effects generated by changes in the teaching-learning methodology, due to the COVID-19 pandemic for a group of university students.

\section{RESULTS}

This section contains relevant information related to the learning habits and perception in the learning process of university students in times of COVID-19. In addition, their sociodemographic conditions are recorded, as well as the technological resources they have to face the new methodologies in the teaching-learning process; similarly, the level of satisfaction with the implemented model and the academic results obtained are shown.

The finding made is hosted on the Google form service, which can be consulted at the following link: https://forms.gle/QMN1wsPwbcxMmyCY7. Questions 1 to 13 extract information related to sex, age, area where they live, type of home ownership, whether they have been displaced by the armed conflict, marital status, number of children and siblings, educational level of parents and the financial situation of the respondents. Questions 14 to 34 detail the characteristics of undergraduate students, describing the conditions in which they are enrolled in the university, as well as the technological equipment they have to face the change in methodology to receive their classes; In addition, questions are asked regarding their learning habits before and after COVID-19 and their perception of the academic development of the courses.

The demographic characteristics of the respondents are presented in Table 1, where it can be observed that about $76 \%$ of the students surveyed are between 20 and 23 years old, $76 \%$ come from urban areas and $24 \%$ from rural areas, $33 \%$ have their own homes and $22 \%$ of the surveyed population has been displaced by the violence that has plagued the country in recent years.

The characterization of the students and their academic conditions are shown in Table 2, where it can be seen that $31 \%$ of the students failed a course, $32 \%$ canceled at least one subject in their academic period and $86 \%$ of the respondents, prefers the traditional teaching methodology in person.

Table 3 shows the effects and perception that students have of the COVID-19 pandemic.

Fig. 1 shows the students' family income, which highlights the fact that the majority have relatively low monthly income. Fig. 2 shows the tools and technological infrastructure used by students in the teaching-learning process during social distancing. Fig. 3 presents the internet connection speeds available to students, and as can be seen, most of those surveyed have a service with internet speeds lower than $5 \mathrm{Mbps}$. Fig. 4 contrasts work time independent (academic activities of students outside the classroom) that students used before Covid-19 and required during Covid-19. Finally, Fig. 5 shows the sources that student's access to stay informed about the status and evolution of the Covid-19 pandemic. 
International Journal of Engineering Research and Technology. ISSN 0974-3154, Volume 13, Number 10 (2020), pp. 2845-2850

(C) International Research Publication House. https://dx.doi.org/10.37624/IJERT/13.10.2020.2845-2850

Table 1. Geodemographic characterization of the university students

\begin{tabular}{|c|c|c|}
\hline Variables & Categories & Percent \\
\hline \multirow{5}{*}{ Age } & $20-21$ years & $37.2 \%$ \\
\hline & $22-23$ years & $38.5 \%$ \\
\hline & $24-25$ years & $11.5 \%$ \\
\hline & $26-27$ years & $11.5 \%$ \\
\hline & 28 and above & $1.3 \%$ \\
\hline \multirow{2}{*}{ Gender } & Female & $29.5 \%$ \\
\hline & Male & $70.5 \%$ \\
\hline \multirow{2}{*}{ Area of living } & Urban & $75.6 \%$ \\
\hline & Rural & $24.4 \%$ \\
\hline \multirow{3}{*}{ Housing Tenure } & Owner occupation & $33.3 \%$ \\
\hline & Familiar house & $51.3 \%$ \\
\hline & Tenancy (Rent) & $15.4 \%$ \\
\hline \multirow{2}{*}{ Displaced by violence } & Yes & $21.8 \%$ \\
\hline & No & $78.2 \%$ \\
\hline \multirow{3}{*}{ Marital Status } & Single/not dating & $91.0 \%$ \\
\hline & Single/but dating & $7.7 \%$ \\
\hline & Married & $1.3 \%$ \\
\hline \multirow{3}{*}{ Number of Children } & Without children & $96.2 \%$ \\
\hline & One & $2.6 \%$ \\
\hline & Two or more & $1.3 \%$ \\
\hline \multirow{5}{*}{ Number of Siblings } & Without siblings & $6.4 \%$ \\
\hline & One & $30.8 \%$ \\
\hline & Two & $25.6 \%$ \\
\hline & Three & $19.2 \%$ \\
\hline & Four or more & $17.9 \%$ \\
\hline \multirow{6}{*}{ Father's Educational Qualification } & Never been to school & $7.7 \%$ \\
\hline & Basic School & $17.9 \%$ \\
\hline & High School & $38.5 \%$ \\
\hline & Degree & $11.5 \%$ \\
\hline & Higher degree & $12.8 \%$ \\
\hline & Others & $11.5 \%$ \\
\hline \multirow{6}{*}{ Mother's Educational Qualification } & Never been to school & $1.3 \%$ \\
\hline & Basic School & $15.4 \%$ \\
\hline & High School & $42.3 \%$ \\
\hline & Degree & $9.0 \%$ \\
\hline & Higher degree & $9.0 \%$ \\
\hline & Others & $23.1 \%$ \\
\hline
\end{tabular}


International Journal of Engineering Research and Technology. ISSN 0974-3154, Volume 13, Number 10 (2020), pp. 2845-2850

(C) International Research Publication House. https://dx.doi.org/10.37624/IJERT/13.10.2020.2845-2850

Table 2. Characterization of the university students

\begin{tabular}{|c|c|c|}
\hline Variables & Categories & Percent \\
\hline \multirow{2}{*}{ Living in a Boarding House } & Yes & $25.6 \%$ \\
\hline & No & $74.4 \%$ \\
\hline \multirow{2}{*}{ What do the students did during the semester? } & Just studying & $66.7 \%$ \\
\hline & Working while studying & $33.3 \%$ \\
\hline \multirow{4}{*}{ Numbers of Enrolled courses } & $1-2$ courses & $5.1 \%$ \\
\hline & $3-4$ courses & $10.3 \%$ \\
\hline & $5-6$ courses & $61.5 \%$ \\
\hline & 7- 8 courses & $23.1 \%$ \\
\hline \multirow{4}{*}{ Numbers of Approved courses } & $1-2$ courses & $14.1 \%$ \\
\hline & $3-4$ courses & $23.1 \%$ \\
\hline & $5-6$ courses & $52.6 \%$ \\
\hline & 7- 8 courses & $10.3 \%$ \\
\hline \multirow{3}{*}{ Numbers of Failed courses } & 0 courses & $69.2 \%$ \\
\hline & 1 course & $24.4 \%$ \\
\hline & 2 courses & $6.4 \%$ \\
\hline \multirow{4}{*}{ Numbers of Courses canceled } & 0 courses & $67.9 \%$ \\
\hline & 1 course & $24.4 \%$ \\
\hline & 2 courses & $1.3 \%$ \\
\hline & 3 or more courses & $6.4 \%$ \\
\hline \multirow{5}{*}{ Reasons to terminate the course } & Lack of technological devices & $1.3 \%$ \\
\hline & Lack of Internet connectivity & $3.8 \%$ \\
\hline & The previous two & $9.0 \%$ \\
\hline & Another reason & $17.9 \%$ \\
\hline & Did not cancel courses & $67.9 \%$ \\
\hline \multirow{2}{*}{ Preferred Instructional Methods } & Face-to-face learning & $85.9 \%$ \\
\hline & Online learning & $14.1 \%$ \\
\hline \multirow{5}{*}{ Preferred e-learning Tools } & Media tools like Zoom or Meet & $69.2 \%$ \\
\hline & Interaction through WhatsApp & $3.8 \%$ \\
\hline & Email & $1.3 \%$ \\
\hline & All of the above & $21.8 \%$ \\
\hline & Did not have access to any & $3.8 \%$ \\
\hline
\end{tabular}

Table 3. Perception of students about the COVID-19 pandemic

\begin{tabular}{|c|c|c|}
\hline \multirow{2}{*}{ Items } & \multicolumn{2}{|c|}{ Responses } \\
\hline & Yes $(\%)$ & No $(\%)$ \\
\hline Do you consider that the classes should continue to be online until a vaccine is found? & $82 \%$ & $18 \%$ \\
\hline $\begin{array}{l}\text { Do you consider that the COVID-19 lockdown has had a negative influence on your academic } \\
\text { performance at university? }\end{array}$ & $58 \%$ & $42 \%$ \\
\hline $\begin{array}{l}\text { Do you consider that the online classes received, because of COVID-19 lockdown, have } \\
\text { decrease the quality education in the enrolled courses? }\end{array}$ & $72 \%$ & $28 \%$ \\
\hline Are you prepared to return to face-to-face classes after the pandemic? & $83 \%$ & $17 \%$ \\
\hline Has COVID-19 affected the work activities of your family and therefore your income? & $92 \%$ & $8 \%$ \\
\hline Has COVID-19 had a high impact on your activities outside the University? & $92 \%$ & $8 \%$ \\
\hline
\end{tabular}


International Journal of Engineering Research and Technology. ISSN 0974-3154, Volume 13, Number 10 (2020), pp. 2845-2850

(C) International Research Publication House. https://dx.doi.org/10.37624/IJERT/13.10.2020.2845-2850

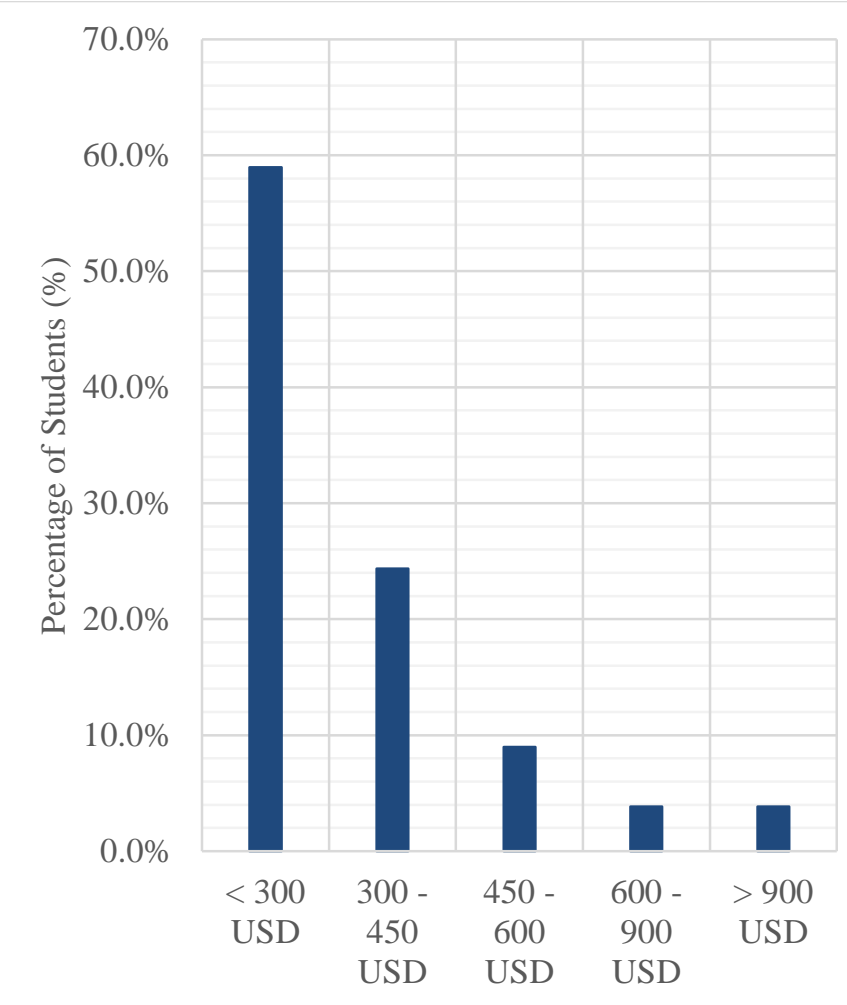

Family Income

Fig. 1. Family Income of the university students

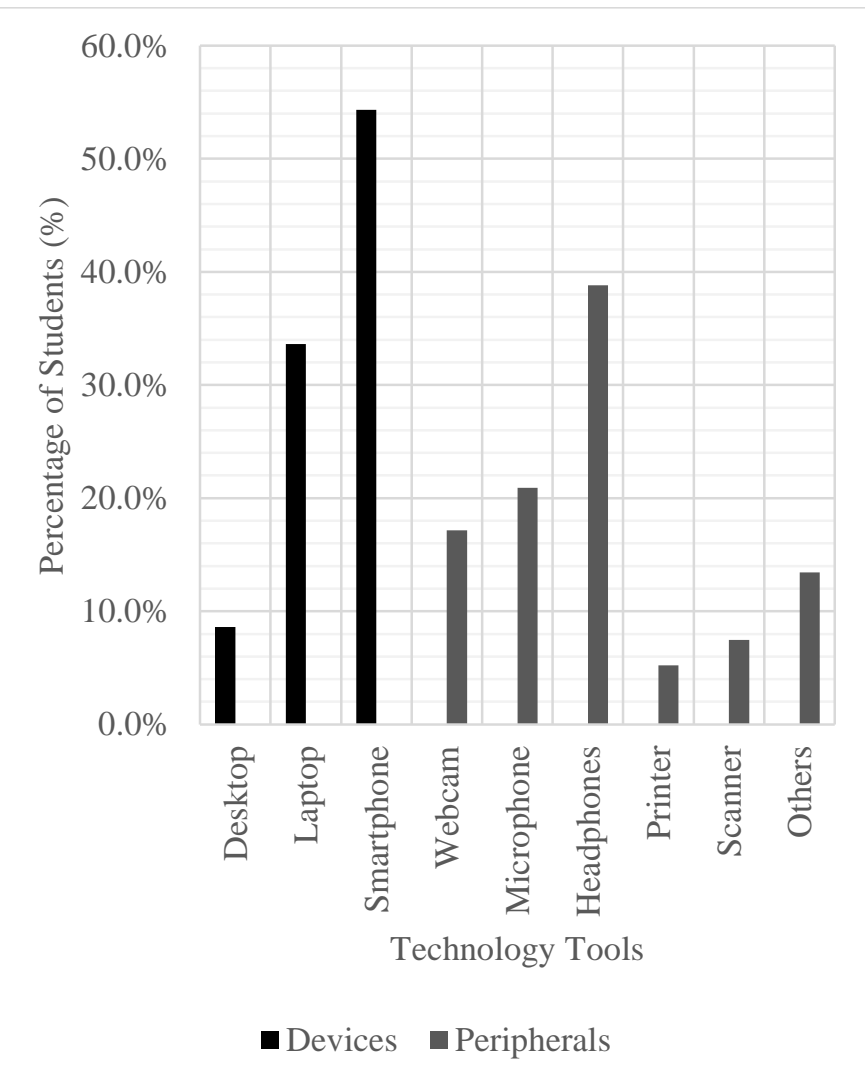

Fig. 2. Technological tools used by university students

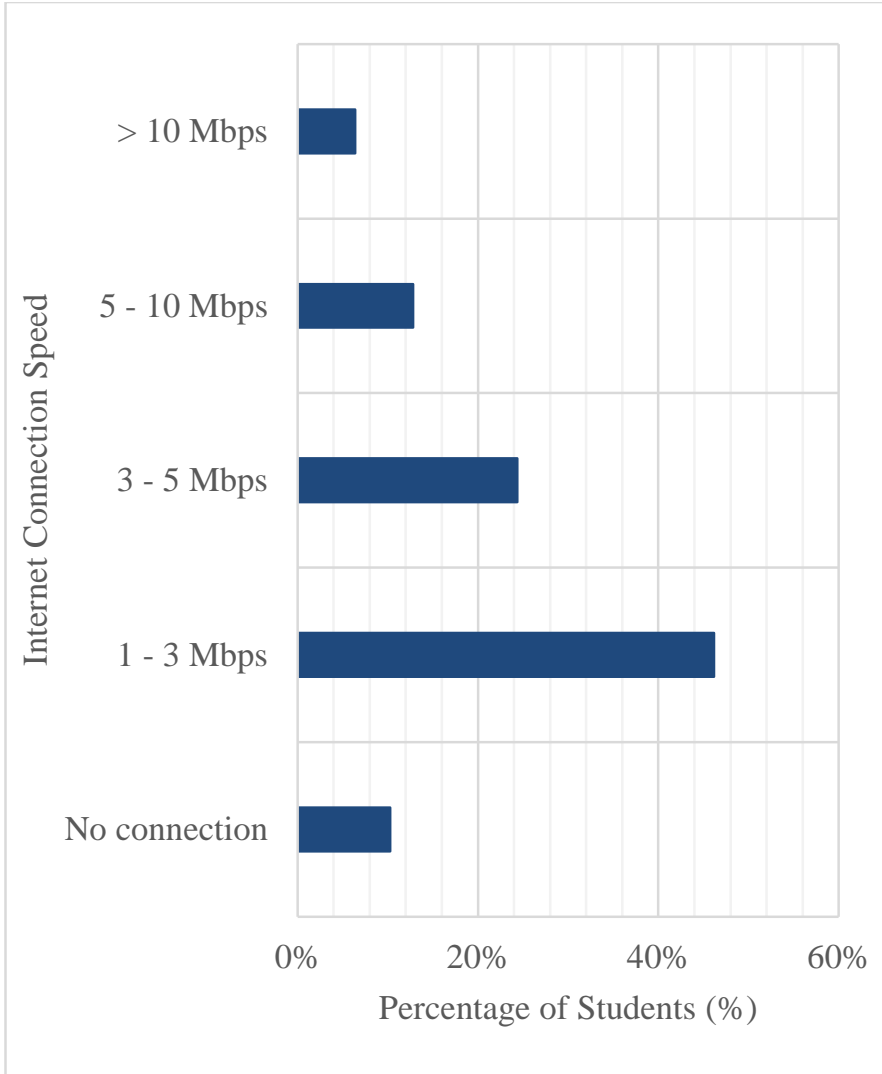

Fig. 3. Internet Connection Speed of the students

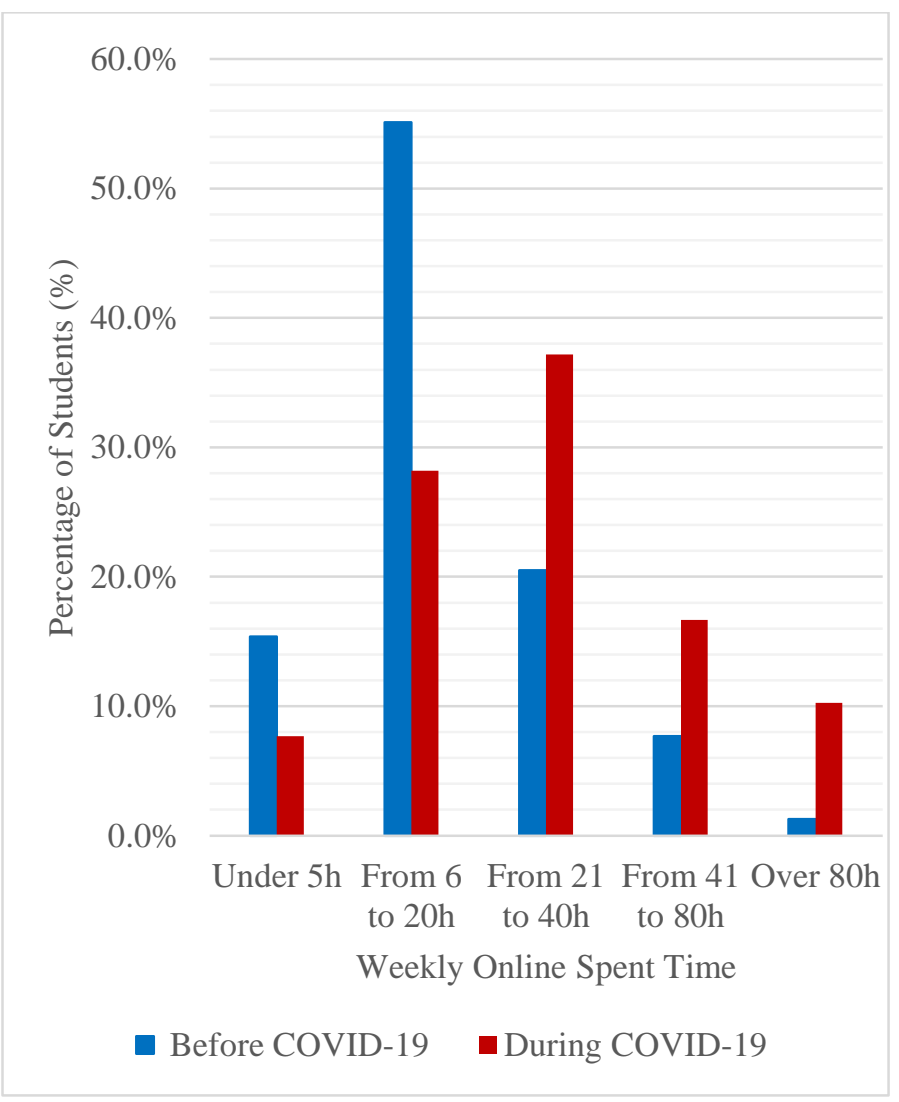

Fig. 4. Weekly Online spent time before and during COVID-19 


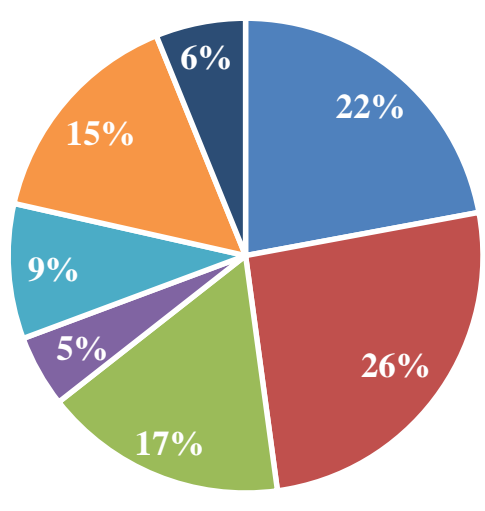

- The mass media (television, newspapers, radio)

- The Internet (Google, Wikipedia, Online Newspaper and Magazines)

- Health workers (doctors, nurses, pharmacist)

- Government officials (governors, ministers, commissioners)

- Friends and family members

- Social media (Whatsapp, Facebook, Instagram, Twitter)

- Does not seek information

Fig. 5. Information sources consulted about COVID-19

\section{CONCLUSIONS}

According to the results obtained, $83 \%$ of the students have a monthly family income of less than 450 USD, which can be considered relatively low, denoting a low purchasing power in the students' families, which could explain the fact that only $34 \%$ of students have laptops, which is why the vast majority connect to classes through their smartphones. Additionally, it was observed that $81 \%$ of those surveyed have a low internet speed, which results in poor connectivity during the teaching of the classes.

On the other hand, it was determined that due to the new virtual learning system implemented, the students had to significantly increase their time of independent dedication in academic activities, which generates an additional workload, complemented by social isolation decreed by the government, it can generate high levels of stress in students.

\section{Acknowledgments}

The authors thank the surveyed students of the Civil Engineering program at the Universidad de Sucre, for their participation in this research.

\section{REFERENCES}

[1] Santos JM. Plan de Desarrollo 2010-2014: Capítulo IV. Igualdad de oportunidades para la prosperidad social, Departamento Nacional de Planeación, Tomo I, pp. 324, $2010 . \quad$ Recuperado de https://colaboracion.dnp.gov.co/CDT/PND/PND20102014\%20Tomo\%20I\%20CD.pdf

[2] Ramírez G, Cossio P. El estado de la educación de las familias en situación de pobreza extrema en Colombia: retos y oportunidades para el siglo XXI, Revista Ciencias Estratégicas. 2015; 23(34): 307 - 319. Recuperado de https://core.ac.uk/download/pdf/297175617.pdf

[3] Comisión Económica para América Latina y el Caribe (CEPAL) y la Oficina Regional de Educación para América Latina y el Caribe de la Organización de las Naciones Unidas para la Educación, la Ciencia y la Cultura (OREALC/UNESCO Santiago). La educación en tiempos
de la pandemia de COVID-19, 2020. Recuperado de https://repositorio.cepal.org/bitstream/handle/11362/4590 4/1/S2000510_es.pdf
[4] Álvarez H, Arias E, Bergamaschi A, López Á, Nole A, Ortiz M, Pérez M, Rieble S, Rivera M, Scannone R, Vásquez M, Viteri A. La educación en tiempos del coranavirus: Los sistemas educativos de América Latina y el Caribe ante COVID-19, Banco Interamericano de Desarrollo (BID), 2020. Recuperado de https://publications.iadb.org/publications/spanish/docume nt/La-educacion-en-tiempos-del-coronavirus-Lossistemas-educativos-de-America-Latina-y-el-Caribe-anteCOVID-19.pdf

[5] Abadía L. El reto que el sector educativo en Colombia debe superar tras la pandemia, Hoy en la Javeriana, Marzo de 2020 .

[6] Cao W, Fang Z, Hou G, Han M, Xu X, Dong J, Zheng J, The psychological impact of the COVID-19 epidemic on college students in China, Psychiatry Research. 287 (2020), Article 112934. https://doi.org/10.1016/j.psychres.2020.112934

[7] Patsali ME, Mousa DV, Papadopoulou EKV, Papadopoulou KKK, Kaparounaki CK, Diakogiannis I, Fountoulakis KN, University students' changes in mental health status and determinants of behavior during the COVID-19 lockdown in Greece, Psychiatry Research. 292 (2020), Article 113298. https://doi.org/10.1016/j.psychres.2020.113298

[8] Nguyen DV, Pham GH, Nguyen DN. Impact of the Covid19 pandemic on perceptions and behaviors of university students in Vietnam, Data in Brief. 31 (2020), Article 105880. https://doi.org/10.1016/j.dib.2020.105880

[9] Caskurlu S, Maeda Y, Richardson JC, Lv J. A metaanalysis addressing the relationship between teaching presence and students satisfaction and learning, Computers \& Education. 157 (2020), Article 103966. https://doi.org/10.1016/j.compedu.2020.103966

[10] Murillo LR, López JÁ, Godoy AL. How the flipped classroom affects knowledge, skills, and engagement in higher education: Effects on students' satisfaction, Computers \& Education. 141 (2019), Article 103608. https://doi.org/10.1016/j.compedu.2019.103608

[11] Trung T, Hoang AD, Nguyen TT, Dinh VH, Nguyen YC, Pham HH. Dataset of Vietnamese student's learning habits during COVID-19, Data in Brief. 30 (2020), Article 105682. https://doi.org/10.1016/j.dib.2020.105682 